\title{
Hubungan antara aktivitas fisik dengan fungsi kognitif pada lansia
}

\author{
Chairina Azkya Noor ${ }^{1}$, Lie Tanu Merijanti ${ }^{2}$
}

\begin{abstract}
ABSTRAK
\section{LATAR BELAKANG}

Seiring dengan meningkatnya jumlah lansia khususnya di Indonesia, semakin meningkat pula permasalahan penyakit akibat proses degeneratif. Tiga puluh dua koma empat persen lansia di Indonesia mengalami gangguan pada fungsi kognitifnya. Fungsi kognitif merupakan salah satu bagian terbesar yang diatur oleh otak. Penuaan menyebabkan terjadinya banyak perubahan pada otak yang dapat mengarah pada kemunduran fungsi neurokognitif. Terdapat beberapa faktor yang diduga dapat memperlambat penurunan fungsi kognitif, salah satunya adalah aktivitas fisik. Studi ini bertujuan untuk mengetahui apakah terdapat hubungan antara aktivitas fisik dengan fungsi kognitif pada lansia.
\end{abstract}

\section{METODE}

Jenis penelitian ini merupakan observational analitic dengan pendekatan cross sectional yang dilakukan pada bulan November 2015. Sampel diambil secara simple random sampling pada 60 lansia di Posyandu Lansia X, Jakarta. Seluruh lansia yang memenuhi kriteria inklusi dinilai aktivitas fisiknya dari pengisian kuesioner Rapid Assessment of Physical Activity (RAPA), sedangkan nilai fungsi kognitif diperoleh dengan wawancara berdasarkan Mini Mental State Examination (MMSE). Analisis data dilakukan untuk mengetahui hubungan antara aktivitas fisik dengan fungsi kognitif pada lansia digunakan uji Chi-square.

\section{HASIL}

Terdapat hubungan bermakna secara statistik antara aktivitas fisik dengan fungsi kognitif pada lansia $(\mathrm{p}=0.000)$.

\section{KESIMPULAN}

Aktivitas fisik dapat mempengaruhi fungsi kognitif pada lansia. Lansia dengan aktivitas fisik golongan regular sampai dengan active memiliki nilai fungsi kognitif yang normal dibandingkan lansia tanpa aktivitas fisik atau termasuk ke dalam golongan under-active.

Kata kunci: aktivitas fisik, fungsi kognitif, lansia
${ }^{1}$ Program Studi Kedokteran, Fakultas Kedokteran Universitas Trisakti, Indonesia

2 Departemen Ilmu Kesehatan Kerja, Fakultas Kedokteran Universitas Trisakti, Indonesia

\section{Korespondensi:}

Lie Tanu Merijanti

Departemen Ilmu Kesehatan Kerja, Fakultas Kedokteran Universitas Trisakti, Indonesia, Jalan Kyai Tapa No. 260, Grogol, Jakarta Barat Email:

liemerijanti@trisakti.ac.id

J Biomedika Kesehat 2020;3(1):8-14 DOI: $10.18051 /$ JBiomedKes.2020. v3.8-14

pISSN: 2621-539X / eISSN: 2621-5470

Artikel akses terbuka (open access) ini didistribusikan di bawah lisensi Creative Commons Attribution 4.0 International (CC-BY 4.0) 


\section{ABSTRACT}

\section{Correlation between physical activity and cognitive function in elderly age}

\section{BACKGROUND}

Along with the increasing number of elderly people in Indonesia, the degenerative disease is also increasing. Thirty two point four percent of elderly people in Indonesia have cognitive function impairment. Cognitive function is one of the biggest parts regulated by brain. Aging causes many changes in the brain that can lead to cognitive function impairment. There are several factors that can postpone the decline of cognitive function; one of them is physical activity. This study aims to determine whether there is correlation between physical activity and cognitive function in elderly.

\section{METHODS}

This research is observational analytic with cross sectional design. Data were collected in November 2015 with simple random sampling method for 60 elderly people at Posyandu Lansia X, Jakarta. Physical Activity was assessed based on Rapid Assessment of Physical Activity (RAPA), and cognitive function was assessed by interview based on Mini Mental State Examination (MMSE). Chi-square test was used to analyze the relationship between physical activity and cognitive function in the elderly.

\section{RESULT}

Based on statistic, there is a relationship between physical activity and cognitive function in the elderly ( $\mathrm{p}=0.000)$.

\section{CONCLUSION}

Physical activity could affect cognitive function in elderly age. Elderly people with the regular-active physical activity had better cognitive function than the inactive (under-active) ones.

Keywords: physical activity, cognitive function, elderly

\section{PENDAHULUAN}

Penuaan merupakan suatu proses irreversible dan angka penduduk lansia semakin mengalami peningkatan. Diperkiran seperempat populasi global akan mencapai usia 65 tahun pada tahun 2020.(1) Penuaan penduduk pada abad ini merupakan suatu fenomena penting yang tidak dapat dihindari baik oleh negara maju maupun negara berkembang. Berdasarkan data Survei Penduduk antar Sensus (Supas) 2015, jumlah lansia di Indonesia mencapai 21.7 juta atau $8.5 \%$ dari seluruh populasi. ${ }^{(2)}$

Di Indonesia sendiri, angka harapan hidup semakin mengalami peningkatan dari 70.1 tahun (periode 2010-2015) menjadi 72.2 tahun pada periode tahun 2030-2035. Namun data angka harapan hidup sehat atau Healthy Life Expectancy (HALE) hanya mencapai 62.1 tahun. Menurut Undang-undang Nomor 13 Tahun 1998, dalam Bab 1 Pasal 1 ayat 2, lanjut usia adalah seseorang yang mencapai usia 60 tahun ke atas. Seiring dengan meningkatnya jumlah lansia khususnya di Indonesia, semakin meningkat pula permasalahan penyakit akibat proses degeneratif. Otak sebagai organ kompleks, pusat pengaturan sistem tubuh dan pusat kognitif, merupakan salah satu organ tubuh yang sangat rentan terhadap proses penuaan atau degeneratif. ${ }^{(2)}$

Penuaan merupakan suatu proses yang natural dan berhubungan erat dengan menurunnya fungsi neurologis seperti kemampuan otak untuk mengirimkan sinyal serta berkomunikasi. Seiring dengan bertambahnya usia, perubahan baik secara fisik maupun fungsional terjadi pada otak. ${ }^{(3)}$

Walaupun penurunan fungsi tersebut disebabkan oleh proses penuaan yang normal, namun perubahan struktur dan fungsi otak juga dapat berhubungan dengan penyakit neurodegenerative salah satunya Alzheimer's disease $(\mathrm{AD}) .^{(4,5)}$

Penuaan menyebabkan terjadinya banyak perubahan pada otak yang dapat mengarah pada kemunduran fungsi neurokognitif. Perubahan tersebut terutama terjadi pada bagian prefrontal dari otak yang memediasi fungsi eksekutif seperti perencanaan dan inisiatif, serta perubahan pada volume hippocampus yang memiliki peran besar dalam daya ingat manusia. ${ }^{(6)}$

Penurunan fungsi kognitif tentunya mempengaruhi individu dan kehidupan sekitarnya termasuk keluarga. Selain itu juga dapat menurunkan kepercayaan diri, kualitas hidup dan fungsinya dalam kehidupan seharihari secara mandiri. (7) Selain penurunan fungsi eksekutif, penurunan fungsi kognitif ditandai dengan penurunan daya ingat maupun konsentrasi, kesulitan mempelajari hal baru atau membuat keputusan, kemunduran orientasi terhadap waku, 
ruang, dan tempat yang mempengaruhi kehidupan sehari-hari. ${ }^{(8,9)}$ Menurut Direktorat Jenderal Pelayanan Medik Kementerian Kesehatan, prevalensi cognitive impairment pada usia lanjut di Indonesia mencapai sekitar 32.4\%. ${ }^{(10)}$

Peningkatan pada fungsi kognitif dan kesehatan otak memiliki konsekuensi yang besar bagi kualitas hidup seseorang. Terdapat beberapa faktor yang diduga dapat memperlambat penurunan fungsi kognitif dan mencegah terjadinya demensia, salah satunya adalah aktivitas fisik. Aktivitas fisik sendiri didefinisikan sebagai gerakan tubuh yang melibatkan otot rangka dan menghasilkan energi. Kegiatan ini disinyalir merupakan salah satu metode yang dipercaya dapat mengurangi risiko penurunan fungsi kognitif terkait usia. ${ }^{(11,12)}$ Beberapa studi menunjukkan bahwa aktivitas fisik merupakan modulator kuat yang dapat menginduksi perubahan positif struktural maupun fungsional pada otak termasuk faktor proteksi terhadap degenerasi neuron. ${ }^{(11)}$

Aktivitas fisik merupakan salah satu strategi untuk menurunkan resiko penurunan fungsi kognitif pada lanjut usia dikarenakan merupakan salah satu kegiatan yang dapat menstimulasi otak. Selain dapat menstimulasi otak, aktivitas fisik pun dapat menurunkan insidensi dan prevalensi terjadinya penyakit kronik yang merupakan salah satu faktor risiko penurunan fungsi kognitif. ${ }^{(13)}$

Studi yang berfokus terhadap peranan aktivitas fisik dalam mempertahankan fungsi kognitif dan mencegah penyakit neurodegeneratif telah dilaksanakan namun bukti dari studi tersebut belum jelas dan konsisten. Beberapa studi menyatakan adanya pengaruh aktivitas fisik terhadap fungsi kognitif terutama pada lansia namun beberapa tidak menemukan hubungan yang signifikan. Dalam hal tersebut, penting untuk mempertimbangkan faktor lain yang dapat mempengaruhi hasil penelitian seperti keterbatasan pengukuran aktivitas fisik, pengukuran fungsi kognitif serta variabilitas pengukuran lainnya. (14) Oleh karena itu, studi ini bertujuan untuk mengetahui apakah terdapat hubungan antara aktivitas fisik dengan fungsi kognitif pada lansia.

\section{METODE}

Metode penelitian yang digunakan adalah penelitian analitik observational dengan pendekatan cross sectional. Penelitian dilakukan

pada November 2015 di Posyandu Lansia X Jakarta. Sampel berjumlah 60 lansia dengan tiga diantaranya drop out. Teknik pengambilan sampel pada penelitian ini menggunakan teknik simple random sampling. Kriteria inklusi mencakup lansia yang dapat berkomunikasi baik dengan Bahasa Indonesia dan tidak mengalami gangguan kejiwaan.

Lansia yang bersedia untuk diwawancarai dan termasuk ke dalam kriteria inklusi akan diberikan kuesioner Rapid Assessment of Physical Activity (RAPA) untuk menilai aktivitas fisik. Lansia dipersilahkan untuk memilih satu dari tujuh pernyataan mengenai aktivitas fisik seharihari. Selanjutnya akan dilakukan wawancara 11 pertanyaan dan perintah berdasarkan Mini Mental State Examination (MMSE) untuk menilai fungsi kognitif. Uji Chi-square digunakan untuk mengetahui hubungan antara aktivitas fisik dengan fungsi kognitif pada lansia. Penelitian ini telah lulus uji kaji etik dari Fakultas Kedokteran Trisakti dengan No. 61/KER-FK/X/2015.

\section{HASIL}

Penelitian dilakukan untuk mengetahui adanya hubungan antara aktivitas fisik dengan fungsi kognitif pada lansia. Berikut merupakan karakteristik responden penelitian berdasarkan usia, status pekerjaan, gologan aktivitas fisik berdasarkan kuesioner Rapid Assessment of Physical Activity (RAPA) dan kategori fungsi kognitf berdasarkan Mini Mental State Examination (MMSE).

Tabel 1. Karakteristik responden

\begin{tabular}{lcc}
\hline Karakteristik & (n) & (\%) \\
\hline Usia & & \\
60-69 tahun & 47 & 82.5 \\
$\quad>70$ tahun & 10 & 17.5 \\
Pekerjaan & & \\
$\quad$ Bekerja & 10 & 17.5 \\
$\quad$ Tidak bekerja & 47 & 82.5 \\
Aktivitas Fisik & & \\
$\quad$ Sedentary & 2 & 3.5 \\
$\quad$ Under-active & 11 & 19.3 \\
$\quad$ Regular under-active & 6 & 10.5 \\
$\quad$ Regular & 25 & 43.9 \\
$\quad$ Active & 13 & 22.8 \\
Fungsi Kognitif & & \\
$\quad$ Normal & 39 & 68.4 \\
$\quad$ Gangguan Kognitif Ringan & 10 & 17.5 \\
$\quad$ Gangguan Kognitif Sedang & 8 & 14 \\
\hline n=jumlah; \%=persentase & &
\end{tabular}


Tabel 2. Hubungan antara aktivitas fisik dengan fungsi kognitif pada lansia

\begin{tabular}{|c|c|c|c|c|c|}
\hline \multirow{3}{*}{ Aktivitas Fisik } & \multicolumn{4}{|c|}{ Fungsi Kognitif } & \multirow{3}{*}{$\mathbf{p}$} \\
\hline & \multicolumn{2}{|c|}{ Normal } & \multicolumn{2}{|c|}{ Gangguan Fungsi Kognitif } & \\
\hline & Jumlah & Persen & Jumlah & Persen & \\
\hline Under-active & 3 & 15.8 & 16 & 84.2 & $0.000^{*}$ \\
\hline Regular-active & 36 & 94.7 & 2 & 5.3 & \\
\hline
\end{tabular}

*Uji Chi-square

Responden pada penelitian ini berjumlah 60 lansia dengan tiga diantaranya drop out, sehingga responden yang memenuhi kriteria inklusi berjumlah 57 lansia. Mayoritas responden $(82.5 \%)$ berada pada rentang usia 60-69 tahun dengan status pekerjaan tidak bekerja.

Berdasarkan hasil dari kuesioner RAPA, aktivitas fisik yang dominan pada lansia di Posyandu Lansia X, Jakarta termasuk ke dalam aktivitas fisik golongan regular (43.9\%). Hal ini menunjukan bahwa distribusi lansia yang melakukan aktivitas fisik lebih banyak dibandingkan lansia yang tidak aktif. Begitupun dengan fungsi kognitif, mayoritas lansia (68.4\%) masih memiliki fungsi kognitif yang normal, dengan prevalensi penurunan fungsi kognitif mencapai 31.5\%.

Berdasarkan Tabel 2, aktivitas fisik memiliki hubungan bermakna dengan fungsi kognitif pada lansia. Lansia dengan aktivitas fisik golongan regular-active, mayoritas $(94.7 \%$ atau 36 responden) memiliki fungsi kognitif normal. Sedangkan dua responden lainnya termasuk ke dalam kategori gangguan fungsi kognitif dengan persentase $5.3 \%$. Dengan demikian didapatkan bahwa pada lansia dengan aktivitas fisik golongan regular-active memiliki skor MMSE yang termasuk ke dalam kategori normal. Sedangkan mayoritas lansia (84.2\%) yang termasuk ke dalam golongan under-active memiliki gangguan fungsi kognitif.

Aktivitas fisik golongan under-active mencakup golongan aktivitas fisik sedentary, under-active, dan regular under-active (light activities/aktivitas ringan). Adapun golongan regular dan active termasuk ke dalam golongan regular-active.

\section{PEMBAHASAN}

Berdasarkan hasil uji Chi-square, didapatkan bahwa terdapat hubungan antara aktivitas fisik dengan fungsi kognitif pada lansia. Sesuai dengan penelitian sebelumnya yang mengemukakan bahwa intensitas aktivitas fisik memiliki pengaruh yang besar terhadap kemampuan kognitif. ${ }^{(15)}$ Studi cohort dengan responden sebanyak 217 orang dan rentang usia antara 60-89 tahun ini mengemukakan bahwa aktivitas fisik yang intens dapat mempengaruhi kesehatan kardiovaskular sehingga menurunkan tekanan darah. Pengaruh ini berhubungan dengan perbaikan fungsi kognitif dan menurunkan risiko terjadinya Alzheimer's Disease (AD). Selain itu, aktivitas fisik yang intens dapat meningkatkan fungsi kardiovaskular yang berpengaruh terhadap peningkatan aliran darah dan perfusi, di mana pada akhirnya akan meningkatkan transpor oksigen ke otak. ${ }^{(15,16)}$ Berdasarkan pemeriksaan yang dilakukan menggunakan Magnetic Resonance Imaging (MRI), keterlibatan seseorang dengan aktivitas fisik selama setahun berkaitan dengan peningkatan volume hippocampus. ${ }^{(16)}$ Bukti ilmiah berdasarkan neuroimaging yang dilakukan dalam beberapa tahun ini telah menunjukan keberhasilan aktivitas fisik dalam meningkatkan kesehatan fungsi kognitif pada lansia. Studi pada hewan percobaan pun menunjukan bahwa aktivitas fisik memiliki manfaat yang baik bagi kesehatan dan neuroplastisitas. ${ }^{(15,17)}$

Total aktivitas fisik, tanpa dipengaruhi faktor lainnya, berhubungan dengan fungsi memori, atensi, dan fungsi eksekutif. Namun, apabila dipengaruhi oleh faktor lain seperti penyakit kardiovaskular dan Indeks Massa Tubuh (IMT), hubungan signifikan ini tidak lagi berhubungan. ${ }^{(15)}$

Hasil penelitian ini sejalan dengan studi cross-sectional terdahulu yang menyatakan bahwa aktivitas fisik berhubungan dengan fungsi kognitif lansia. Lebih jauh dinyatakan bahwa aktivitas fisik 
yang intens dianjurkan untuk dilakukan sejak usia muda untuk menurunkan risiko gangguan fungsi kognitif pada lanjut usia. ${ }^{(18)}$ Pada studi ini ditemukan bahwa wanita lansia tidak aktif secara fisik memiliki fungsi kognitif yang lebih buruk dan prevalensi gangguan kognitif yang lebih tinggi dibandingkan wanita lansia aktif. Aktivitas fisik menurunkan kejadian berbagai faktor penyakit vaskular seperti hipertensi, obesitas, dan diabetes yang berhubungan dengan meningkatnya kejadian gangguan fungsi kognitif. Selain itu, dikatakan bahwa aktivitas fisik memiliki efek positif terhadap fungsi kognitif melalui pengaruhnya terhadap brain-derived neurotropic factor (BDNF). ${ }^{(18)}$ Salah satu hipotesis yang dapat menjelaskan hubungan antara aktivitas fisik dan fungsi kognitif adalah melalui jalur neurotrophin otak. Neurotrophin merupakan suatu protein yang mempengaruhi perkembangan dan fungsi dari saraf. Diantara neurotrophin lain, BDNF merupakan neurotrophin yang paling banyak diekspresikan pada otak sehingga mempengaruhi diferensiasi neuron dan proteksi dari kematian neuron di hippocampus. (16) Aktivitas fisik mempengaruhi produksi dari BDNF pada area penting yang mengatur memori, seperti hippocampus. ${ }^{(17)}$

Studi terdahulu menyatakan bahwa olah raga aerobik lebih efektif dalam memperlambat proses degeneratif yang berpengaruh terhadap penurunan fungsi kognitif secara fisiologis. ${ }^{(19)}$ Hubungan antara aktivitas fisik dengan fungsi kognitif ini pun sesuai dengan hasil studi yang lain yang menyatakan bahwa partisipan dengan kemungkinan gangguan kognitif berupa Mild Cognitive Impairment (MCI) memiliki aktivitas fisik yang lebih rendah disertai dengan gaya hidup sedenter dibandingkan partisipan tanpa gangguan kognitif. Dimana penilaian fungsi kognitif ditetapkan menggunakan perangkat ADAS-Cog. (20)

Hasil dari penelitian ini pun diperkuat dengan studi yang menyatakan bahwa responden dengan aktivitas fisik efektif dengan level moderat ataupun tinggi kecil kemungkinannya mengalami gangguan kognitif. Lebih jelas dinyatakan bahwa terdapat hubungan signifikan antara rendahnya aktivitas fisik dan rendahnya fungsi kognitif pada responden. ${ }^{(21)}$ Partisipan yang mempertahankan atau meningkatkan aktivitas fisik mereka memiliki risiko penurunan fungsi kognitif 3.6 kali lebih kecil, diukur berdasarkan skor Mini Mental State Examination (MMSE). ${ }^{(22)}$

Studi terbaru juga memperkuat hipotesis hubungan antara aktivitas fisik dengan fungsi kognitif pada lansia. Studi ini menunjukkan bahwa aktivitas fisik memiliki efek yang menguntungkan bagi fungsi kognitif, terutama fungsi visuospatial dan menurunkan risiko terjadinya dementia. Perlu dicatat bahwa skor awal Montreal Cognitive Assessment (MoCA) dan Mini-Mental States Examination (MMSE) lebih tinggi pada kelompok self-selected exercise dibandingkan kelompok self-selected non-exercise begitu pula pada pemeriksaan yang diulang 1 tahun setelahnya. ${ }^{(1)}$

Penelitian lain mememperlihatkan bahwa intervensi aktivitas fisik tidak berhubungan dengan fungsi kognitif pada lansia. Kemungkinan hal ini terjadi karena intervensi aktivitas fisik yang tidak cukup maksimal untuk mempengaruhi fungsi kognitif, uji klinis yang berlangsung singkat serta variabilitas responden penelitian. Lebih lanjut dijelaskan bahwa intervensi gaya hidup selama 24 bulan tidak meningkatkan fungsi kognitif. ${ }^{(23)}$

Sebagian besar studi sebelumnya melaporkan hasil bahwa terdapat hubungan bermanfaat yang signifikan antara aktivitas fisik terhadap fungsi kognitif pada lansia. ${ }^{(16-20)}$ Namun terdapat pula hasil studi yang berbeda, dimana tidak ditemukan adanya hubungan antara keduanya. ${ }^{(23)}$ Dalam hal ini terdapat berbagai macam faktor yang dapat mempengaruhi. Salah satu faktor yang dapat dipertimbangkan yaitu masing-masing studi memiliki pedoman, kriteria dan teori serta pendekatan metode yang berbeda. Selain itu, variabilitas pengambilan data, pengukuran dan parameter variabel baik fungsi kognitif maupun aktivitas fisik dapat menyebabkan hasil dan kesimpulan yang heterogen. Khususnya parameter aktifitas fisik, sangat penting untuk dipahami mekanisme aktivitas fisik seperti apa yang memungkinkan untuk memberikan pengaruh terhadap fungsi kognitif. Selain itu penggunaan perangkat untuk menilai variabel yang berbedabeda juga dapat mempengaruhi hasil penelitian. ${ }^{(11)}$

Faktor durasi yang relatif singkat pada suatu studi juga dapat mempengaruhi hasil evaluasinya, di mana aktivitas fisik dan pengaruhnya terhadap fungsi kognitif merupakan suatu akumulasi yang terlihat dalam jangka waktu yang panjang. Sehingga studi observasional 
dengan follow-up atau cohort merupakan pendekatan yang ideal untuk mengatasi kendala tersebut. ${ }^{(14)}$

\section{KESIMPULAN}

Berdasarkan hasil penelitian yang telah dilakukan, didapatkan kesimpulan bahwa aktivitas fisik terbukti berpengaruh terhadap fungsi kognitif lansia. Golongan aktivitas fisik yang berhubungan dengan nilai fungsi kognitif yang baik adalah golongan regular-active. Peneliti selanjutnya yang hendak melakukan penelitian mengenai aktivitas fisik dan fungsi kognitif pada lansia agar menggunakan rancangan penelitian selain crosssectional sehingga dapat melihat seberapa kuat hubungan dari kedua variabel tersebut. Selain itu, penilaian aktivitas fisik sebaiknya dilakukan dengan metode lain selain wawancara atau kuesioner sehingga tidak bersifat subjektif.

\section{UCAPAN TERIMA KASIH}

Pengurus Posyandu Lansia Samara yang telah mengizinkan dan menyempatkan waktunya untuk turut serta dalam penelitian ini.

\section{REFERENSI}

1. Lin S, Yang Y, Qi Q, et al. The beneficial effect of physical exercise on cognitive function in a nondementia aging Chinese population. Front Aging Neurosci. 2019 Aug 29;11:238. doi: 10.3389/ fnagi.2019.00238

2. Cicih LSM. Info Demografi [Internet]. [Jakarta]: Badan Kependudukan dan Keluarga Berencana Nasional (BKKBN). 2019 [cited 2019 Dec 11] Available from: https://www.bkkbn.go.id/pocontent/uploads/info demo vol 12019 jadi.pdf

3. Amarya $\mathrm{S}$, Singh K, Sabharwai $\overline{\mathrm{M}}$. Ageing process and physiological changes. In: D'Onofrio G, Greco A, Sancarlo D, editors. Gerontology [Internet]. IntechOpen; 2018. Available from: https://www. intechopen.com/books/gerontology/ageingprocess-and-physiological-changes. doi: 10.5772/ intechopen.76249

4. Kirk-Sanchez NJ, McGough EL. Physical exercise and cognitive performance in the elderly: Current perspectives. Clin Interv Aging. 2013;9:51-62. doi:10.2147/CIA.S39506

5. Ho JA, Raji CA, Becker JT, et al. The effects of physical activity, education, and body mass index on the aging brain. Hum Brain Mapp. 2011 Sep;32(9):1371-82. doi: 10.1002/hbm.21113

6. Eggermont L, Milberg WP, Lipsitz LA, et al. Physical activity and executive function in aging: the MOBILIZE Boston study. J Am Geriatr Soc. 2009 Oct;57(10):1750-6. doi: 10.1111/j.15325415.2009.02441.x

7. Gheysen F, Poppe L, DeSmet A, et al. Physical activity to improve cognition in older adults: Can physical activity programs enriched with cognitive challenges enhance the effects? A systematic review and meta-analysis. Int J Behav Nutr Phys Act. 2018 Jul 4;15(1):63. doi: 10.1186/s12966018-0697-x

8. Henneges C, Reed C, Chen YF, et al. Describing the sequence of cognitive decline in alzheimer's disease patients: Result from an observational study. J Alzheimers Dis. 2016;52(3):1065-80. doi: 10.3233/JAD-150852

9. Tripathi RK, Tiwari SC. Cognitive Dysfunction in Normally Aging Urban Older Adults: A Community-based Study. Indian J Psychol Med. 2011;33(2):177-181. doi:10.4103/02537176.92059

10. Abadi K, Wijayanti D, Gunawan EA, et al. Hipertensi dan Risiko Mild Cognitive Impairment pada Pasien Usia Lanjut. Kesmas Natl Public Heal J. 2013;8(3):115. doi:10.21109/kesmas.v8i3.354

11. Erickson KI, Hillman C, Stillman CM, et al. Physical Activity, Cognition, and Brain Outcomes: A Review of the 2018 Physical Activity Guidelines. Med Sci Sports Exerc. 2019;51(6):1242-1251. doi:10.1249/MSS.0000000000001936

12. Bherer L, Erickson KI, Liu-Ambrose T. A review of the effects of physical activity and exercise on cognitive and brain functions in older adults. J Aging Res. 2013;2013: 657508. doi: $10.1155 / 2013 / 657508$

13. Morley, JE. Cognition and chronic disease. Journal of the American Medical Directors Association. 2017;18(5):369-71. https://doi.org/10/1016/J. JAMDA.2017.02.010

14. Hamer M, Terrera GM, Demakakos P. Physical activity and trajectories in cognitive function: English longitudinal study of ageing. J Epidemiol Community Health. 2018;72(6):477-483. doi:10.1136/jech-2017-210228

15. Brown BM, Peiffer JJ, Sohrabi HR, et al. Intense physical activity is associated with cognitive performance in the elderly. Transl Psychiatry. 2012;2(11):e191-6. doi:10.1038/tp.2012.118

16. Phillips C, Baktir MA, Srivatsan $M$, et al. Neuroprotective effects of physical activity on the brain: A closer look at trophic factor signaling. Front Cell Neurosci. 2014;8(JUN):1-16. doi:10.3389/fncel.2014.00170

17. Pinilla GF, Hilman C. The influence of exercise on cognitive abilities. Compr Physiol. 2013;1:403-28. doi: $10.1002 /$ cphy.c110063

18. Middleton LE, Barnes DE, Lui LY, et al. Physical activity over the life course and its association with cognitive performance and impairment in old age. J Am Geriatr Soc. 2010;7:1322-6. doi: 10.1111/j.1532-5415.2010.02903.x

19. Carvalho A, Rea IM, Parimon T, et al. Physical activity and cognitive function in individuals over 60 years of age: A systematic review. Clin Interv Aging. 2014;9:661-682. doi:10.2147/CIA.S55520

20. Falck RS, Landry GJ, Best JR, et al. Crosssectional relationship of physical activity and sedentary behavior with cognitive function in older adults with probable mild cognitive impairment. American Physical Therapy Association. 2017;10(97): 975-82

21. Yang M, Guo Y, Gong J, et al. Relationships between functional fitness and cognitive impairment in chinese community-dwelling older adults: A Cross-sectional Study. BMJ Open. 2018;8:1-6. doi: 10.1136/bmjopen-2017-020695

22. Wreksoatmodjo BR. Beberapa Kondisi Fisik dan 
Penyakit Merupakan Faktor Risiko Gangguan Fungsi Kognitif. CKD 2014;41:25-32

23. Sink KM, Espeland MA, Castro CM, et al. Effect of a 24-month physical activity intervention compared to health education on cognitive outcomes in sedentary older adults: the LIFE randomized trials. JAMA. 2015;8:781-90. doi:10.1001/jama.2015.9617 